\title{
Editorial
}

\section{Beyond the Lamfalussy Report}

Since the launch of the Euro in January 1999, it has become increasingly apparent that Europe lacks the integrated financial markets needed to exploit the full potential of European Monetary Union. Progress towards a single market in financial services is hindered by the existence of 15 different national systems of financial legislation and regulation, and by slow and rigid European Community procedures. Though the principles of home-country control, mutual recognition and minimum harmonisation have proven successful in advancing the European Community's goal of creating a single market in financial services, they are not without limitations. These limitations have become apparent in the process of integrating securities markets in Europe.

The Lamfalussy Report ${ }^{1}$ (ie the Final Report of the Committee of Wise Men on the Regulation of European Securities Markets, which was published on 15th February, 2001 and adopted by the European Council in Stockholm of 23-24 March) focuses on the question of 'how' to speed up reform, that is on the processes and legal procedures needed to reform securities markets regulation, rather than on the question of 'what' needs to be reformed.

In a shorter-term perspective, it is no doubt rational for the European institutions and governments to focus on these procedures. The need for speeding up the legislative process is rather obvious as capital markets change fast and, on past experience, the adoption of directives in the field of financial regulation takes 2-3 years, followed by a 1-2 year period for national transposition. By definition directives are always running behind events in the markets.

The major novelty of the Report is a proposed four-level regulatory approach, whose aim is to speed up the legislative process for the regulation of securities markets. Of these four levels, the main innovation is the distinction between 'core principles' in Level 1 and 'technical implementing matters' in Level 2, which mirrors at the EU level what happens at the national level, with the distinction between primary legislation and secondary regulation. According to Baron Lamfalussy, the Report brings about a 'governance change,' a bottom-up (rather than topdown) approach, which could also be applied to other areas of European integration.

In a longer-term perspective the two major issues at stake are, in my opinion, the creation of a single securities European regulator and the adoption of basic standards of securities regulation (or a basic code of European securities regulation). The Report stops short of proposing the former (though leaves the door open through a fall-back remark) and calls for the reform of the Investment Services Directive (ISD) and the prompt adoption of other measures included in the Commission's Financial Services Action Plan.

There are two contrasting views on financial supervision in Europe. The first, supported, in particular, by the UK, thinks that greater cooperation between national regulators, and increased harmonisation through competitive pressures and self-reg- 
ulation, would best pave the road to a more efficient and integrated capital market. The second view, which finds support in France and some other continental countries, deems that supervision in Europe would be performed better by a centralised agency than by a large number of national authorities. Whether or not a new institution will be created will, however, depend on the political will of the Member States.

The Lamfalussy Report suggests that, '...If the full review were to confirm in 2004 (or earlier as the case may be) that the approach did not appear to have any prospect of success, it might be appropriate to consider a Treaty change, including the creation of a single EU regulatory authority for financial services generally in the Community.' (Lamfalussy Report at p. 41). I had the opportunity of asking Baron Lamfalussy whether the wording of this statement was intentional when he spoke in London on 3rd May, 2001 and his answer was positive: the choice of words, single EU regulatory authority for financial services in the Community' was intentional. This means that the Report seems to indicate a preference for the conceivable creation of a European FSA rather than for the creation of a European SEC.

Whether or not a European SEC (or a European FSA) is ever created, it is necessary for academics and practitioners to commence a thorough discussion on its possible institutional design. Such a debate ought to focus on the structure, functions and accountability of such a new institution. Just to say that such an agency should not be created would tempt those who most fervently favour its creation to 'capture' the debate and to advance their cause in their own terms, which could appear 'too centralising' or 'bureaucratic' to those who oppose its creation. Such an approach, in the absence of adequate opposition, may lead to an inadequate institutional design. For instance, I think that the alleged democratic deficit of the European Central Bank might have been remedied or alleviated through a more thorough ex ante debate on accountability. Had such a debate taken place (akin to the debate that preceded the enacting of legislation in the UK granting operational independence to the Bank of England) those who opposed the creation of such a new institution, could have 'minimised' its perceived damage by suggesting features of greater democratic participation and transparency.

Europe does need a well-functioning capital market. If the current structure does not work efficiently enough - and there seems to be broad consensus that this is the case - then, such structure needs to be reformed. Greater efficiency, however, cannot be achieved at the expense of compromising democratic legitimacy and accountability.

Rosa M. Lastra

Senior Lecturer in International Financial and Monetary Law, Centre for Commercial Law Studies, Queen Mary College, University of London July 2001

\section{References}

(1) See http://europa.eu.int/comm/internal_ market/en/finances/general/lamfalussy.htm

This Editorial draws on a forthcoming publication written by Rosa M. Lastra. 